National and Global Petroleum Assessment

\title{
Assessment of Undiscovered Gas Hydrate Resources in the North Slope of Alaska, 2018
}

\author{
Using a geology-based assessment methodology, the U.S. Geological Survey estimated undiscovered, technically recoverable \\ mean resources of about 54 trillion cubic feet of gas resources within gas hydrates in the North Slope of Alaska.
}

\section{Introduction}

Gas hydrates are naturally occurring, ice-like solids in which water molecules trap gas molecules in a cage-like structure known as a clathrate. Although many gases form hydrates in nature, methane hydrate is by far the most common. Gas hydrates were identified in laboratory studies in the early 1800s and were first theorized to occur in nature in the 1960s. Studies of geophysical seismic data, industry-acquired well logs and cores, and extensive geologic system modeling studies conducted over the last several decades have confirmed the existence of gas hydrates in numerous sedimentary basins in terrestrial permafrost and deep-marine environments (Collett and others, 2015). In 2008, the U.S. Geological Survey (USGS) completed the first assessment of the technically recoverable gas hydrate resources in the North Slope of Alaska (Collett and others, 2008; U.S. Geological Survey Alaska Gas Hydrate Assessment Team, 2013). Since the 2008 USGS gas hydrate assessment, one of the most studied permafrost-associated gas hydrate accumulations has been the Eileen Gas Hydrate Trend on the Alaska North Slope. The Eileen Gas Hydrate Trend has been the focus of two gas hydrate scientific drilling programs: (1) the Mount Elbert gas hydrate stratigraphic test well project (Anderson and others, 2011; Collett and others, 2011) and (2) the Ignik Sikumi gas hydrate production test well project (Boswell and others, 2017). The science and engineering studies in support of these two programs have yielded one of the most comprehensive datasets of the occurrence of gas hydrates in an Arctic permafrost setting.

The USGS has updated the previous 2008 assessment of undiscovered, technically recoverable gas hydrate resources beneath the North Slope of Alaska. This new 2018 assessment again indicates the existence of technically recoverable gas hydrate resources-that is, resources that can be discovered, developed, and produced using current technology.

The approach used in this assessment followed standard, geology-based USGS methodologies developed to assess conventional oil and gas resources. To use the USGS conventional assessment approach on gas hydrate resources, extensive industry and research-well databases (Lorenson and Collett, 2011; Lewis and Collett, 2013) and three-dimensional (3D), industry-acquired seismic data were analyzed. The analyses indicated that the gas hydrates in the Alaska North Slope occupy limited, discrete volumes of rock bounded by faults and downdip water contacts. This assessment approach also assumes that the resources can be produced using existing conventional technology based on limited field testing and numerical production models of gas hydrate-bearing reservoirs (Anderson and others, 2011; Nandanwar and others, 2016).

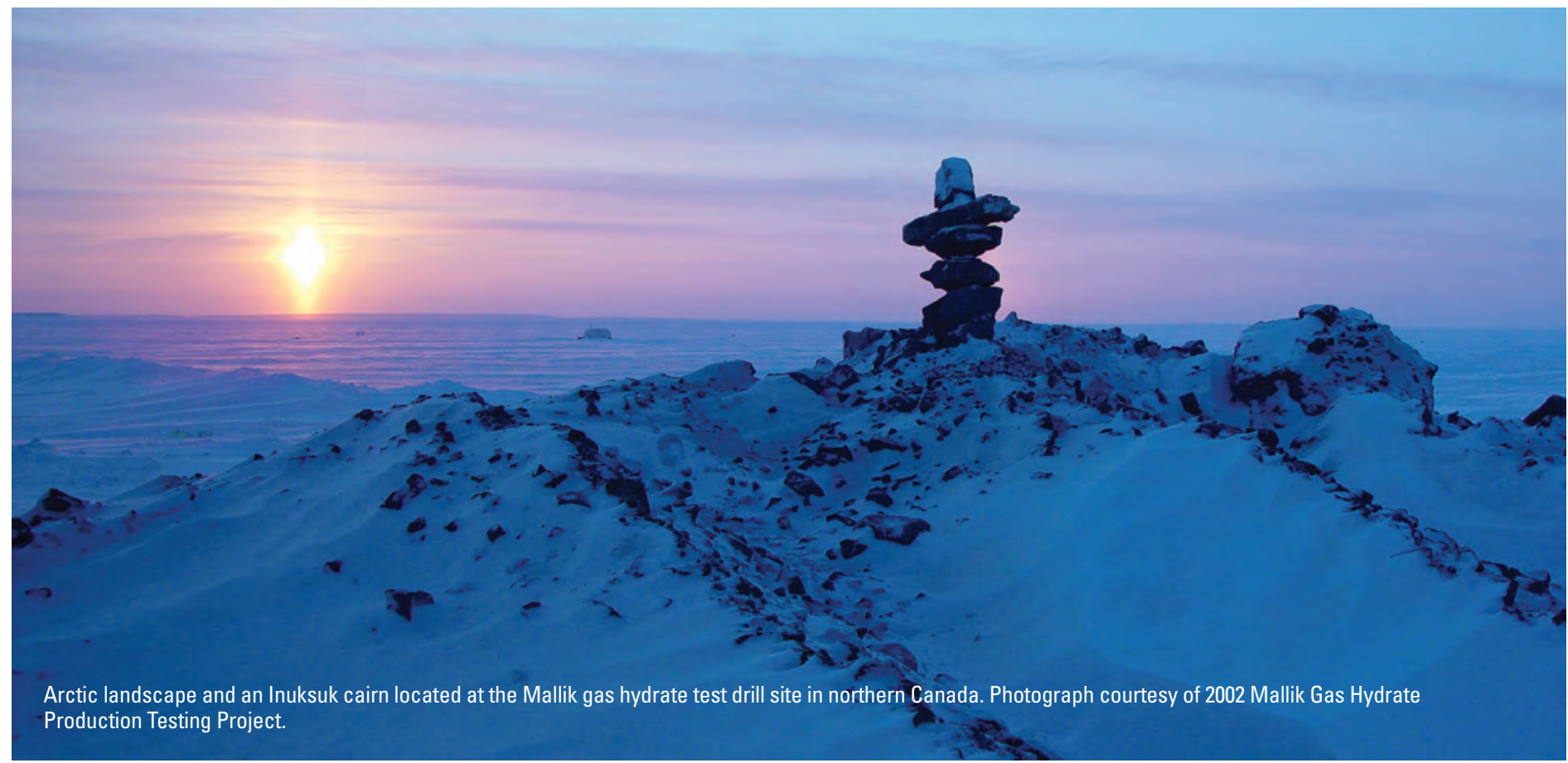




\section{Geological Framework and Definition of Assessment Units}

The area assessed in the North Slope of Alaska extends from the National Petroleum Reserve-Alaska (NPR-A) on the west through the Arctic National Wildlife Refuge (ANWR) on the east and from the Brooks Range northward to the State-Federal offshore boundary (located 3 miles north of the coastline) (fig. 1). This area covers 41,089 square miles and consists mostly of Federal, State, and Native lands.

The USGS oil and gas assessment methodology begins with the volume of rock to be assessed in the total petroleum system (TPS) being apportioned into subunits termed assessment units (AUs). The assessment procedure generally estimates the number and size of undiscovered hydrocarbon accumulations and assesses the geologic risk associated with each AU. The Northern Alaska Gas Hydrate TPS includes Cretaceous and Tertiary reservoir rocks divided into three AUs (fig. 1), listed from oldest to youngest: the Nanushuk Formation Gas Hydrate AU, the Tuluvak-Schrader Bluff-Prince Creek Formations Gas Hydrate AU, and the Sagavanirktok Formation Gas Hydrate AU.

The geologic model used to define the AUs and to set the limits of the TPS involved defining and characterizing the parts of the gas hydrate petroleum system (including gas hydrate stability conditions, gas hydrate reservoirs, and gas source and migration) that control the presence of gas hydrate accumulations in each AU (Collett and others, 2011). As a first step, the factors controlling gas hydrate phase equilibria (which are mostly a function of formation temperature and pressure) are used to map the distribution of the gas hydrate stability zone. Characterization of the potential reservoir rocks within the mapped gas hydrate stability zone yielded the three AUs defined in this study. Only gas hydrates below the permafrost section were assessed, thus limiting the AUs to the stratigraphic interval below the base of the permafrost and above the base of the gas hydrate stability zone. Free-gas potentially trapped below the gas hydrate stability zone was not assessed.

Two of the critical parts of the USGS assessment procedure are the accurate predictions of the expected size and number of undiscovered hydrocarbon accumulations within each of the delineated AUs (table 1). This assessment of the gas hydrate resources in the North Slope of Alaska relied heavily on the analysis of industry-acquired 3D seismic data, which were used to characterize the size, number, and distribution of gas hydrate accumulations in each of the three AUs. The minimum accumulation size considered was 30 billion cubic feet of technically recoverable gas. USGS scientists used established gas hydrate seismic attribute analysis techniques (Lee and others, 2009) to identify 103 seismically inferred gas hydrate accumulations throughout the Northern Alaska Gas Hydrate TPS. These seismically inferred gas hydrate accumulations were used in this assessment to estimate the size and number of gas hydrate accumulations in each AU (table 1).

Geochemical analyses of drill cuttings and core samples from wells drilled in the State of Alaska lands between the Canning and Colville Rivers and within NPR-A indicate that the gas within the drilled and well log inferred gas hydrate accumulations is in part from thermogenic sources, with the thermogenic gas migrating from deeper sources, including known conventional oil and gas accumulations (Collett and others, 2011; Lorenson and Collett, 2011). Thermal conditions conducive to the formation of permafrost and gas hydrates are believed to have persisted in the Arctic since the end of the Pliocene (about 2.58 million years ago) (Collett and others, 2011). In addition, most permafrost-associated gas hydrate accumulations probably developed from preexisting free-gas fields that originally formed in conventional hydrocarbon traps and were later converted to gas hydrates upon the onset of glaciation and cold Arctic conditions. Project-acquired gas geochemistry data

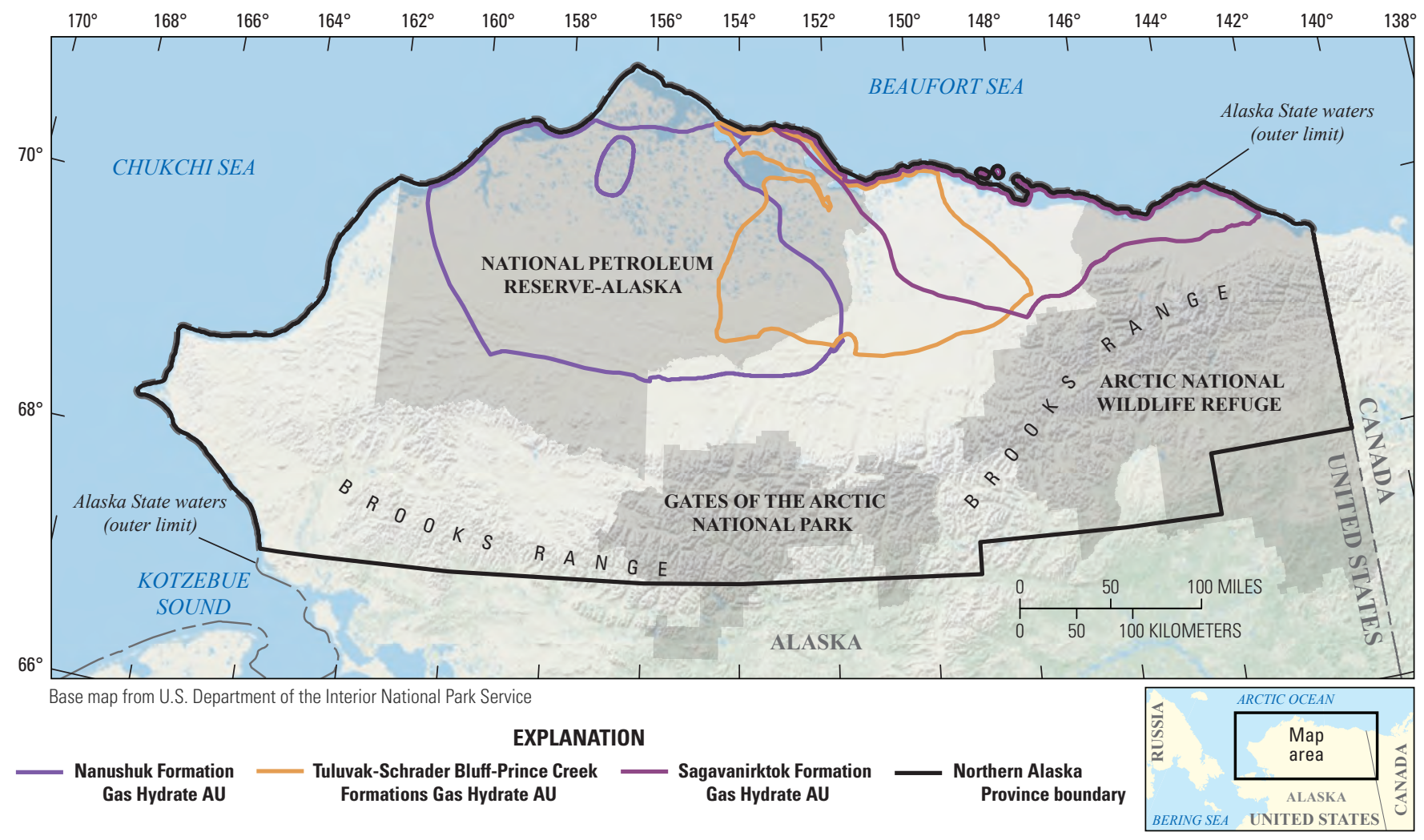

Figure 1. Map of the Northern Alaska Province, showing boundaries of the three gas hydrate assessment units (AUs). Adjacent lines illustrate a shared boundary at the outermost line. 
Table 1. Key input data for three gas hydrate assessment units in the Northern Alaska Province.

[AU, assessment unit; BCFG, billion cubic feet of gas. Shading indicates not applicable]

\begin{tabular}{|c|c|c|c|c|c|c|c|c|}
\hline \multirow{2}{*}{$\begin{array}{c}\text { Assessment input data- } \\
\text { Conventional AUs }\end{array}$} & \multicolumn{4}{|c|}{ Nanushuk Formation Gas Hydrate AU } & \multicolumn{4}{|c|}{$\begin{array}{c}\text { Tuluvak-Schrader Bluff-Prince Creek Formations } \\
\text { Gas Hydrate AU }\end{array}$} \\
\hline & Minimum & Median & Maximum & $\begin{array}{l}\text { Calculated } \\
\text { mean }\end{array}$ & Minimum & Median & Maximum & $\begin{array}{c}\text { Calculated } \\
\text { mean }\end{array}$ \\
\hline Number of gas fields & 1 & 100 & 400 & 110.3 & 1 & 90 & 360 & 99.2 \\
\hline Size of gas fields (BCFG) & 30 & 70 & 11,000 & 217.4 & 30 & 65 & 10,000 & 197.3 \\
\hline AU probability & 0.9 & & & & 0.9 & & & \\
\hline \multirow{2}{*}{$\begin{array}{c}\text { Assessment input data- } \\
\text { Conventional AU }\end{array}$} & \multicolumn{4}{|c|}{ Sagavanirktok Formation Gas Hydrate AU } & & & & \\
\hline & Minimum & Median & Maximum & $\begin{array}{c}\text { Calculated } \\
\text { mean }\end{array}$ & & & & \\
\hline Number of gas fields & 1 & 150 & 600 & 165.4 & & & & \\
\hline Size of gas fields (BCFG) & 30 & 50 & 3,000 & 98.9 & & & & \\
\hline AU probability & 0.9 & & & & & & & \\
\hline
\end{tabular}

Table 2. Results for three gas hydrate assessment units in the Northern Alaska Province.

[BCFG, billion cubic feet of gas; NGL, natural gas liquids; MMBNGL, million barrels of natural gas liquids. Results shown are fully risked estimates. For gas accumulations, all liquids are included in the NGL category. F95 represents a 95-percent chance of at least the amount tabulated; other fractiles are defined similarly. Fractiles are additive under the assumption of perfect positive correlation. Shading indicates not applicable]

\begin{tabular}{|c|c|c|c|c|c|c|c|c|c|c|}
\hline \multirow{3}{*}{$\begin{array}{l}\text { Total petroleum system } \\
\text { and assessment units (AUs) }\end{array}$} & \multirow{3}{*}{$\stackrel{\text { AU }}{\text { probability }}$} & \multirow{3}{*}{$\begin{array}{l}\text { Accumulation } \\
\text { type }\end{array}$} & \multicolumn{8}{|c|}{ Total undiscovered resources } \\
\hline & & & \multicolumn{4}{|c|}{ Gas (BCFG) } & \multicolumn{4}{|c|}{ NGL (MMBNGL) } \\
\hline & & & F95 & F50 & F5 & Mean & F95 & F50 & F5 & Mean \\
\hline \multicolumn{11}{|c|}{ Northern Alaska Gas Hydrate Total Petroleum System } \\
\hline Nanushuk Formation Gas Hydrate AU & 0.9 & Gas & 0 & 19,978 & 46,706 & 21,511 & 0 & 0 & 0 & 0 \\
\hline $\begin{array}{l}\text { Tuluvak-Schrader Bluff-Prince Creek } \\
\text { Formations Gas Hydrate AU }\end{array}$ & 0.9 & Gas & 0 & 16,231 & 38,449 & 17,608 & 0 & 0 & 0 & 0 \\
\hline Sagavanirktok Formation Gas Hydrate AU & 0.9 & Gas & 0 & 13,840 & 30,475 & 14,677 & 0 & 0 & 0 & 0 \\
\hline Total undiscovered conventional resources & & & 0 & 50,049 & 115,630 & 53,796 & $\mathbf{0}$ & $\mathbf{0}$ & $\mathbf{0}$ & 0 \\
\hline
\end{tabular}

and information about the distribution of conventional oil and gas accumulations, and their petroleum system linkage to potential gas hydrate accumulations, were used in this assessment to help predict the number of inferred gas hydrate accumulations in each AU (table 1).

The USGS conventional assessment approach also assumes that the hydrocarbon resources being assessed can be produced using existing conventional technology. The production potential of the seismically inferred gas hydrate accumulations in the Alaska North Slope has not been fully field tested; however, these same inferred accumulations have been the focus of a U.S. Department of Energy gas hydrate production research modeling effort and of short-duration field production tests. Although verified only by limited field testing, numerical production models of gas hydrate-bearing reservoirs indicate that gas can be produced from gas hydrates with existing conventional technology (Anderson and others, 2011; Nandanwar and others, 2016; Boswell and others, 2017). This allows the use of the USGS conventional assessment methodology to assess the technically recoverable gas hydrate resources in northern Alaska.

\section{Undiscovered Gas Hydrate Resources Summary}

The estimated mean total for the three Alaska North Slope gas hydrate AUs is 53,796 billion cubic feet of gas (BCFG, recoverable) (table 2). These estimates are associated with large ranges of uncertainty (table 2, range of results between F95 and F5), which reflect the immature stage of exploration for this potential resource and concerns associated with producibility of gas hydrates. Of the
Northern Alaska Gas Hydrate TPS mean estimate of 53,796 BCFG, about 27 percent $(14,677 \mathrm{BCFG})$ is within the Sagavanirktok Formation Gas Hydrate AU, 33 percent (17,608 BCFG) is within the Tuluvak-Schrader Bluff-Prince Creek Formations Gas Hydrate AU, and 40 percent $(21,511$ BCFG) is within the Nanushuk Formation Gas Hydrate AU. Given that relatively few wells have penetrated the expected gas hydrate accumulations in these three AUs, there is significant geologic uncertainty in these estimates, as reflected in the range shown in table 2 . Because of the remaining uncertainty associated with the producibility of gas hydrates, each AU probability was risked at a factor of 0.9 , which resulted in the estimate that the total undiscovered gas resources at the F95 probability for each AU could be zero.

The estimated mean total of 53,796 BCFG within the gas hydrates in the Northern Alaska Gas Hydrate TPS is less than the 85,427 BCFG reported in the 2008 USGS assessment (Collett and others, 2008; U.S. Geological Survey Alaska Gas Hydrate Assessment Team, 2013). Because of access to additional 3D seismic data volumes and well-log datasets, this 2018 assessment features improved mapping of all three AUs. The Tuluvak-Schrader Bluff-Prince Creek Formations and Nanushuk Formation Gas Hydrate AUs were determined to be smaller and cover less physical area, which resulted in the reduction of the number of estimated gas hydrate accumulations in each AU. The increase of the minimum field-size cutoff from 20 BCFG in 2008 to 30 BCFG in 2018 for all three AUs also contributed to the lower estimated gas volumes in this 2018 assessment. 


\section{Acknowledgments}

The research project in support of this assessment was a cooperative effort with the Bureau of Land Management, which also provided access to most of the 3D seismic data used to define the gas hydrate AUs and to delineate gas hydrate accumulations for this assessment.

\section{References Cited}

Anderson, B.J., Kurihara, M., White, M.D., Moridis, G.J., Wilson, S.J., Pooladi-Darvish, M., Gaddipati, M., Masuda, Y., Collett, T.S., Hunter, R.B., Narita, H., Rose, K., and Boswell, R., 2011, Regional long-term production modeling from a single well test, Mount Elbert Gas Hydrate Stratigraphic Test Well, Alaska North Slope: Marine and Petroleum Geology, v. 28, no. 2, p. 493-501, accessed September 28, 2018, at https://www.sciencedirect.com/science/article/pii/S0264817210000176.

Boswell, R., Schoderbek, D., Collett, T.S., Ohtsuki, S., White, M., and Anderson, B.J., 2017, The Ignik Sikumi Field Experiment, Alaska North Slope-Design, operations, and implications for $\mathrm{CO}_{2}-\mathrm{CH}_{4}$ exchange in gas hydrate reservoirs: Energy and Fuels, v. 31, p. 140-153, accessed September 28, 2018, at https://pubs.acs.org/doi/abs/10.1021/ acs.energyfuels.6b01909.

Collett, T.S., Agena, W.F., Lee, M.W., Zyrianova, M.V., Bird, K.J., Charpentier, R.R., Cook, T.A., Houseknecht, D.W., Klett, T.R., Pollastro, R.M., and Schenk, C.J., 2008, Assessment of gas hydrate resources on the North Slope, Alaska, 2008: U.S. Geological Survey Fact Sheet 2008-3073, 4 p., accessed September 28, 2018, at https://pubs.usgs.gov/fs/2008/3073.

Collett, T., Bahk, J.-J., Baker, R., Boswell, R., Divins, D., Frye, M., Goldberg, D., Husebo, J., Koh, C., Malone, M., Morell, M., Myers, G., Shipp, C., and Torres, M., 2015, Methane hydrates in nature-Current knowledge and challenges: Journal of Chemical and Engineering Data, v. 60, no. 2, p. 319-329, accessed September 28, 2018, at https://pubs.acs.org/doi/abs/10.1021/je500604h.
Collett, T.S., Lee, M.W., Agena, W.F., Miller, J.J., Lewis, K.A., Zyrianova, M.V., Boswell, R., and Inks, T.L., 2011, Permafrost-associated natural gas hydrate occurrences on the Alaska North Slope: Marine and Petroleum Geology, v. 28, no. 2, p. 279-294, accessed September 28, 2018, at https://www.sciencedirect.com/science/ article/pii/S0264817209002177.

Lee, M.W., Collett, T.S., and Inks, T.L., 2009, Seismic-attribute analysis for gas-hydrate and free-gas prospects on the North Slope of Alaska, in Collett, T.S., Johnson, A., Knapp, C., and Boswell, R., eds., Natural gas hydrates-Energy resource potential and associated geologic hazards: American Association of Petroleum Geologists Memoir 89, p. 541-554.

Lewis, K.A., and Collett, T.S., 2013, Brookian sequence well log correlation sections and occurrence of gas hydrates, north-central North Slope, Alaska: U.S. Geological Survey Scientific Investigations Report 2013-5050, 23 p., accessed September 28, 2018, at https://pubs.usgs.gov/sir/2013/5050.

Lorenson, T.D., and Collett T.S., 2011, Gas hydrate prospecting using well cuttings and mud-gas geochemistry from 35 wells, North Slope, Alaska: U.S. Geological Survey Scientific Investigations Report 2011-5195, 27 p., accessed September 28, 2018, at https://pubs.usgs.gov/ sir/2011/5195.

Nandanwar, M.S., Anderson, B.J., Ajayi, T., Collett, T.S., and Zyrianova, M.V., 2016, Evaluation of gas production potential from gas hydrate deposits in the National Petroleum Reserve Alaska using numerical simulations: Journal of Natural Gas Science and Engineering, v. 30, p. 760-772, accessed September 28, 2018, at https://www.sciencedirect.com/ science/article/pii/S187551001630823X?via\%3Dihub.

U.S. Geological Survey Alaska Gas Hydrate Assessment Team, 2013, National assessment of oil and gas project — Geologic assessment of undiscovered gas hydrate resources on the North Slope, Alaska: U.S. Geological Survey Digital Data Series 69-CC, 100 p., accessed September 28, 2018, at https://doi.org/10.3133/ds69CC.
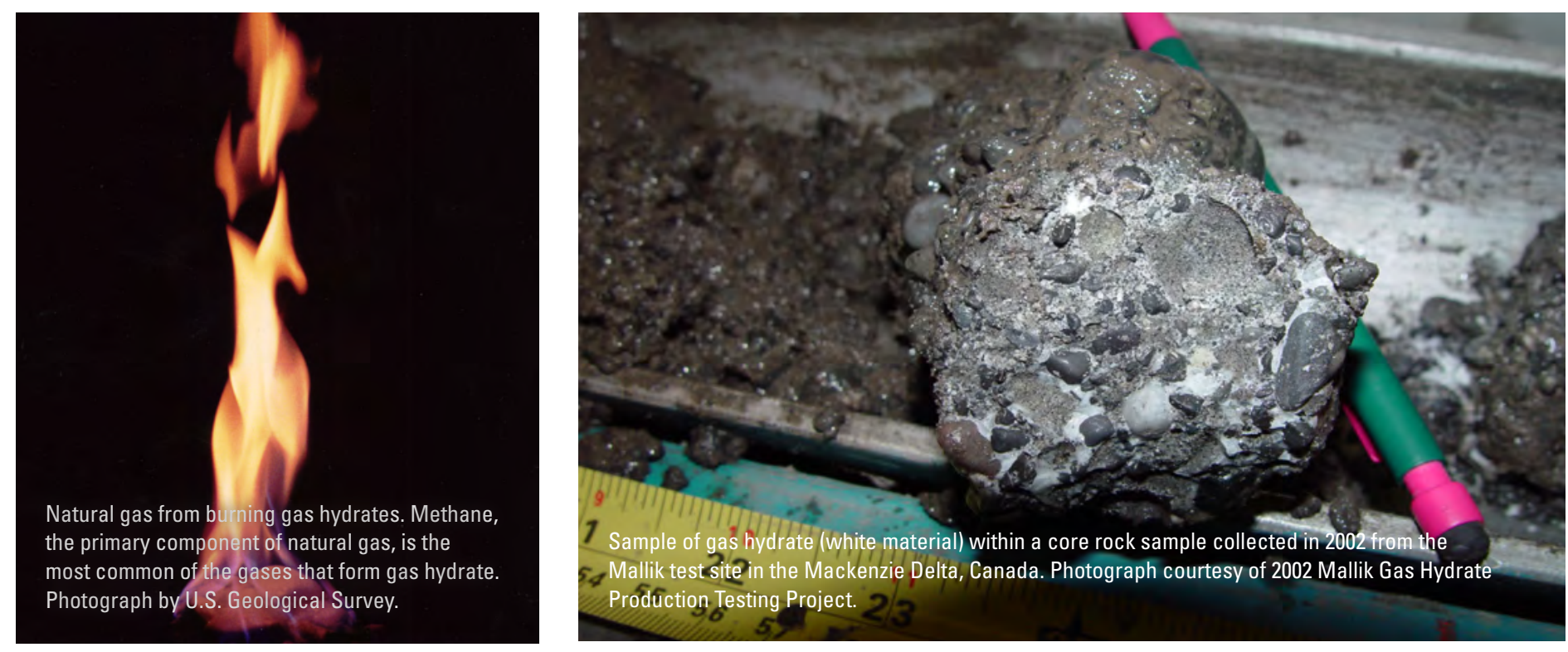

\section{Alaska Gas Hydrate Assessment Team}

Timothy S. Collett, Kristen A. Lewis, Margarita V. Zyrianova, Seth S. Haines, Christopher J. Schenk, Tracey J. Mercier, Michael E. Brownfield, Stephanie B. Gaswirth, Kristen R. Marra, Heidi M. Leathers-Miller, Janet K. Pitman, Marilyn E. Tennyson, Cheryl A. Woodall, and David W. Houseknecht

\section{For More Information}

Assessment results are also available at the USGS Energy Resources Program website at https://energy.usgs.gov. 